\title{
Effect of composting and soil type on dissipation of veterinary antibiotics in land-applied manures
}

\author{
Chaoqi Chen ${ }^{\text {a, * }}$, Partha Ray ${ }^{\text {b, d }}$, Katharine F. Knowlton ${ }^{\text {b }}$, Amy Pruden ${ }^{\text {, }}$, Kang Xia ${ }^{\text {a }}$ \\ a Department of Crop and Soil Environmental Sciences, Virginia Tech, Blacksburg, VA 24061, United States \\ b Department of Dairy Science, Virginia Tech, Blacksburg, VA 24061, United States \\ ${ }^{\mathrm{c}}$ Department of Civil \& Environmental Engineering, Virginia Tech, Blacksburg, VA 24061, United States \\ ${ }^{\mathrm{d}}$ Division of Animal, Dairy \& Food Chain Sciences, School of Agriculture, Policy and Development, Univ. of Reading, Reading RG6 6AR, UK
}

\section{H I G H L I G H T S}

- Antibiotic dissipation follows bi-phasic first-order kinetics in manure-amended soils.

- Antibiotic dissipation obeys single-phase first-order kinetics in compost-amended soils.

- Manure-borne antibiotics persist in soils at low concentrations.

- Soil type had negligible effect on dissipation kinetics of manure-borne antibiotics.

- Composting can reduce antibiotic resistance selection potential of manure in soils.

\section{A R T I C L E I N F O}

\section{Article history:}

Received 15 September 2017

Received in revised form

12 December 2017

Accepted 24 December 2017

Available online 26 December 2017

Handling Editor: Klaus Kümmerer

\section{Keywords:}

Environmental fate

Antibiotics

Dairy

Beef

Soil

Risk assessment

\begin{abstract}
A B S T R A C T
The objective of this study was to determine the fate of commonly used veterinary antibiotics in their naturally excreted form when manure-based amendments are applied to soil. Beef cattle were administered sulfamethazine, tylosin, and chlortetracycline and dairy cows were treated with pirlimycin. The resulting manure was composted for $42 \mathrm{~d}$ under static or turned conditions and applied at agronomic $\mathrm{N}$ rates to sandy, silt, and silty clay loam soils and compared with amendment with corresponding raw manures in sacrificial microcosms over a 120-day period. Antibiotic dissipation in the raw manureamended soils followed bi-phasic first order kinetics. The first phase half-lives for sulfamethazine, tylosin, chlortetracycline, and pirlimycin ranged from 6.0 to $18,2.7$ to $3.7,23$ to 25 , and $5.5-8.2 \mathrm{~d}$, respectively. During the second phase, dissipation of sulfamethazine was negligible, while the half-lives for tylosin, chlortetracycline, and pirlimycin ranged from 41 to 44,75 to 144 , and 87-142 d, respectively. By contrast, antibiotic dissipation in the compost-amended soils followed single-phase first order kinetics with negligible dissipation of sulfamethazine and half-lives of tylosin and chlortetracycline ranging from 15 to 16 and 49-104d, respectively. Pirlimycin was below the detection limit in the compost-amended soils. After incubating $120 \mathrm{~d}$, antibiotics in compost-amended soils (up to $3.1 \mu \mathrm{g} \mathrm{kg}^{-1}$ ) were significantly lower than in manure-amended soils (up to $19 \mu \mathrm{g} \mathrm{kg}^{-1}, p<.0001$ ), with no major effect of soil type on the dissipation. Risk assessment suggested that composting can reduce antibiotic resistance selection potential in manure-amended soils.
\end{abstract}

() 2018 Elsevier Ltd. All rights reserved.

\section{Introduction}

Antibiotics are widely used in livestock for therapeutic and subtherapeutic purposes (Chee-Sanford et al., 2009). About $80 \%$ of the 13.5 million kilograms of antibiotics sold yearly in the USA is used

\footnotetext{
* Corresponding author.

E-mail address: chaoqi3@vt.edu (C. Chen).
}

in animal production (Done et al., 2015), among which macrolides are categorized as "critically important" while sulfonamides, tetracyclines and lincosamides are categorized as "highly important" in human medicine by the World Health Organization (Collignon et al., 2016). Administered antibiotics are not fully metabolized, leading to their excretion in animal manure (Chiesa et al., 2015). For example, $17-75 \%$ of chlortetracycline or $28-76 \%$ of tylosin was excreted into manure in unchanged forms (Montforts et al., 1999; 
Jjemba, 2002). In the environment, soil is the primary receiver of antibiotics used in animal production, mainly through land application of manure (Jechalke et al., 2014). A wide range of antibiotics has been detected worldwide in various manures and manureamended soils, at concentrations up to several thousand $\mu \mathrm{g} \mathrm{kg}^{-1}$ (Martinez-Carballo et al., 2007; Ho et al., 2014; Li et al., 2015; Yang et al., 2016).

Although composting has been proposed as a mean to reduce antibiotic levels in manure before land application, recent studies have indicated that it cannot completely remove antibiotics (Dolliver et al., 2008; Cessna et al., 2011; Ray et al., 2017). A major concern is that antibiotics released into soils could exert a selective pressure on the native microbial community (Cleary et al., 2016; Nordenholt et al., 2016) and enrich antibiotic resistant bacteria and resistance genes (Jechalke et al., 2014).

Previous studies demonstrated that antibiotic dissipation in soils is influenced by environmental factors, such as temperature, $\mathrm{pH}$, and soil physicochemical properties, as well as the initial concentrations of antibiotics and their associated matrixes (Otker and Akmehmet-Balcioglu, 2005; Cengiz et al., 2010; Srinivasan and Sarmah, 2014). Chemical properties of the antibiotics can also influence their interactions with soil minerals and organic matter (Otker and Akmehmet-Balcioglu, 2005; Wegst-Uhrich et al., 2014). To date, investigation of the fate of antibiotics in soils has largely been conducted using antibiotic-spiked soils or soils mixed with antibiotic-spiked manure (Carlson and Mabury, 2006; Fang et al., 2014; Pan and Chu, 2016). Although such approaches are in accordance with the US EPA guidelines for pesticides (USEPA., 2008a, b), they do not consider the effects of passing through the animal gut and subsequent manure management on the interactions of antibiotics with the manure matrix before land application. Such influences are important because: 1) antibiotics typically enter the soil via a manure matrix, whereas pesticides are normally directly applied to soils; 2 ) passage through the animal gut will influence their sorption within the manure matrix, partially biodegrade antibiotics, and place selection pressure on and shape microbial communities involved; and 3) manure amendment alters soil physical, chemical, and biological properties, all of which will influence the fate of antibiotics.

Although there is limited information comparing the environmental fate of manure-borne versus spiked antibiotics, studies of biosolids have demonstrated significantly faster dissipation rates of the antimicrobial triclosan when spiked directly into soils compared to when it is biosolids-borne (Kwon and Xia, 2012). Thus, decreased diffusion, increased sorption, and reduced bioavailability of organic amendment-borne could contribute to prolonged persistence, compared to predicted values and those determined using spiked soils.

The objective of this study was to determine the effect of composting and soil type on the dissipation of manure-borne antibiotics following land application, using manure derived from antibiotic-administered dairy cows and beef cattle. The results help to evaluate whether benefits of composting using FDA FSMA guidelines (FDA, 2014) extend towards reducing antibiotics and their potential impacts in soils, particularly within the USDA National Organic Program's recommended 120-day waiting period between raw manure application and harvest of crops that are in contact with soil (USDA, 2012).

\section{Materials and methods}

\subsection{Raw manure and compost}

Raw manure was collected from sulfamethazine, tylosin and chlortetracycline-treated beef cattle or pirlimycin-treated dairy cows (Table S1 and Text S1 of Supplemental Information (SI)). After laboratory-scale composting for $42 \mathrm{~d}$, using static and turned techniques as recommended by the FDA (FDA, 2014) and described in a previous study (Ray et al., 2017), compost was collected from composting tumblers (Text S1, SI). The physical properties and antibiotic concentrations in raw manure and the compost are listed in Table S2.

\subsection{Soil microcosms}

The sandy loam, silt loam, and silty clay loam soils were top soils $(0-5 \mathrm{~cm})$ collected from three locations in Virginia (Text S2, SI and Table S3).

For each microcosm unit, $15 \mathrm{~g}$ air-dried soil sieved through 2$\mathrm{mm}$ was added to a $150 \mathrm{~mL}$ pre-washed (70\% ethanol) and airdried glass jar. Calculated based on the typical agronomic nitrogen application rate in Virginia (Evanylo, 2009), $2.44 \mathrm{~g}$ raw manure or $1.60 \mathrm{~g}$ compost was then added to a glass jar and mixed by hand shaking and stirring. Ultrapure water was added to the manure-soil mixture to bring the soil moisture to $50 \%$ of its field moisture capacity and maintained by recording the total weight of each microcosm jar. Each jar was covered loosely with an aluminum foil sheet to reduce moisture loss while maintaining aerobic conditions. All microcosms were kept in the dark at room temperature $\left(20^{\circ} \mathrm{C}\right)$ with soil moisture adjusted weekly by adding ultrapure water to bring the total weight of each jar to its recorded weight. Soils were collected in triplicate on days $0,1,3,7,29,57,90$ and 120 via destructive sampling, freeze dried, and stored at $-20^{\circ} \mathrm{C}$ for antibiotics analysis.

Antibiotics were extracted and cleaned up using solid phase extraction and subsequently analyzed by ultra performance liquid chromatography - tandem mass spectrometer (Ray et al., 2014, 2017). For pirlimycin, external matrix-match standard method was used. For sulfamethazine, tylosin, and chlortetracycline, internal standard method was used. Sulfamerazine, roxithromycin, and oxytetracycline were selected as internal standards, according to previous reports (Smallidge and Albert, 2000; Benetti et al., 2004; Halling-Sorensen et al., 2005). The internal standards were used to correct for the loss of analyte during sample preparation and compensate potential matrix effects. Details of the methods have been described previously and further QA/QC information is provided in the Supplemental Information (Text S3, SI). The method quantification limits (MQLs) of sulfamethazine, tylosin, chlortetracycline, and pirlimycin were $0.43,0.83,1.95$, and $1.78 \mu \mathrm{g} \mathrm{kg}^{-1}$ in manure amended soils, respectively. The recoveries for the four target antibiotics were found to range from 58 to $121 \%$ in manure amended soils.

\subsection{Data graphing and statistical analysis}

Bi-phasic or single phasic first order kinetic models were used to fit the $C_{t} / C_{0}$ vs $t$ curves. The rate constants were acquired based on the slope of the curve fit of $\ln \left(C_{t} / C_{o}\right)$ vs $t$ to the respective model and the half-lives were derived from the calculated rate constants. If all triplicate samples were non-detect, then the $C_{t} / C_{o}$ point was noted as below the detection limit (BDL).

All statistical analyses were carried out using JMP (JMP ${ }^{\circledR}$, Version 12.0. SAS Institute Inc. Cary, NC, 1989-2007). For nondetect samples, half of the method detection limit was used for statistical purposes. Two-way analysis of variance (ANOVA) was carried out at the 95\% confidence level to test the effects of amendment type (raw manure, static compost, or turned compost), soil type, and their interactions on antibiotic dissipation. One-way ANOVA was used to test the effect of amendment type on the final antibiotic concentrations in soils at the end of microcosm study. 
Multiple paired comparisons were conducted using the TukeyKramer method (Tukey, 1949).

\subsection{Assessment of antibiotic resistance selection potential}

Risk quotient (RQ) values were applied to assess the potential impact of antibiotic residue on antibiotic resistance selection potential in soils at day 0 and $120 \mathrm{~d}$ after manure application. The RQ values were calculated as the ratios of the measured concentrations in the soils before and after incubation (Table 1) to the predicted no-effect concentrations for antibiotic resistance selection in soils $\left(\right.$ PNECS $\left._{\text {soil }}\right)$. The predicted no-effect concentration in soil for an antibiotic $\left(\mathrm{PNEC}_{\text {soil }}\right)$ can be calculated using the following equations (Thomaidi et al., 2016):

$\mathrm{PNEC}_{\text {soil }}=\mathrm{PNEC}_{\text {water }} \times k_{d}=\mathrm{PNEC}_{\text {water }} \times k_{o c} \times f_{o c}$

Where $\mathrm{PNEC}_{\text {water }}$ is the predicted no-effect concentration for resistance selection in water $\left(\mu \mathrm{g} \mathrm{L}^{-1}\right), k_{d}$ is the soil-water partition coefficient of the antibiotic $\left(\mathrm{L} \mathrm{kg}^{-1}\right), k_{\mathrm{oc}}$ is the soil organic carbonwater partitioning coefficient of the antibiotic. The $\mathrm{PNEC}_{\text {soil }}$ for sulfamethazine, tylosin, chlortetracycline, and pirlimycin were estimated (Text S4, SI) and ranged from 58 to $100,7.0-12,0.68-1.2$, and $10-18 \mu \mathrm{g} \mathrm{kg}^{-1}$, respectively (Table S8). Similar to the classification used for ecological risk evaluation (Ho et al., 2015), RQ values $<0.1,0.1-1$, and $>1$ are categorized into three levels, as "low", "medium", and "high" antibiotic resistance selection potentials, respectively.

\section{Results and discussion}

\subsection{Antibiotic dissipation patterns in the soil microcosms}

The term "dissipation" is used here to refer to the collective effects of biodegradation, transformation, sorption, loss of extractability, and other processes that contribute to a net decrease in measured antibiotic. Limited field studies have reported the dissipation of manure-borne antibiotics (Halling-Sorensen et al., 2005; Heuer et al., 2008). While such field studies are of value to gain a general sense of antibiotic behavior in the real world, it is not possible to isolate the effects of specific environmental processes governing their fate. For example, transport, plant uptake, and photodegradation will all influence to some extent the persistence of antibiotics in soils at field-scale and cannot be distinguished from other processes, such as biodegradation. In contrast, microcosms provide the advantage of a closed system with a limited number of variables.

\subsubsection{Raw manure-amended soils}

The initial concentrations (dry weight basis) of sulfamethazine, tylosin, and chlortetracycline in the three cattle manure-amended soils ranged from 29 to $47,8.4$ to 10 , and $46-80 \mu \mathrm{g} \mathrm{kg}^{-1}$, respectively (Table 1 ). These concentrations were more relevant to realworld conditions compared to levels typically spiked to soils (100-1,000,000 $\mathrm{g} \mathrm{kg}^{-1}$ ) (Accinelli et al., 2007; Pan and Chu, 2016).

Dissipation of sulfamethazine was rapid in all three soils within the first $7 \mathrm{~d}$, with $43-77 \%$ remaining at day 7 (Fig. 1), but slowed significantly thereafter. Sulfamethazine concentration remained constant at levels of $32-45 \%$ in the three soils until day 120 (Fig. 1). Our observations are consistent with a prior field study examining the dissipation of five sulfonamides, including sulfamethazine, in manure-amended soils (Stoob et al., 2007), where the dissipation was initially fast, but slowed down considerably after $14 \mathrm{~d}$. Similar results were also reported when examining the sulfamethazine dissipation in a swine manure-amended sandy loam soil with an initial spiked concentration of $100,000 \mu \mathrm{g} \mathrm{kg}^{-1}$ (Lertpaitoonpan et al., 2015). Other studies of structurally-related sulfonamides also yielded similar results (Wang et al., 2006; Liu et al., 2010; Fang et al., 2014). For example, the dissipation of sulfadiazine was rapid within $7 \mathrm{~d}$ of incubation, followed by dramatically slower dissipation in manure-amended soils with an initial spiked concentration of $20,000 \mu \mathrm{g} \mathrm{kg}^{-1}$ (Fang et al., 2014). These studies support the overall conclusion that sulfamethazine becomes more persistent and less bioavailable with time.

Similar to the case with sulfamethazine, initial dissipation of tylosin was rapid in raw manure-amended soils (Fig. 1). By day 7 , $44-58 \%$ of tylosin remained in the three soils. However, in contrast to sulfamethazine, the dissipation of tylosin continued throughout the 120-day incubation period, although at a slower rate. By day 120 , only $5.9-8.4 \%$ of tylosin remained in the three soils, with final concentrations ranging from 0.51 to $0.87 \mu \mathrm{g} \mathrm{kg}^{-1}$ (Fig. 1, Table 1). Continuous dissipation of tylosin in soils was observed in previous studies (Halling-Sorensen et al., 2005; Carlson and Mabury, 2006; Schlusener and Bester, 2006; Hu and Coats, 2007; Sassman and Lee, 2007; Liu et al., 2010). A field study using manure-borne antibiotics showed that the concentrations of tylosin declined from 50 to $10 \mu \mathrm{g} \mathrm{kg}^{-1}$ in a sandy loam soil and from 25 to $3 \mu \mathrm{g} \mathrm{kg}^{-1}$ in a sand soil within $155 \mathrm{~d}$ (Halling-Sorensen et al., 2005).

The trend in the dissipation of chlortetracycline in the raw manure-amended soils was similar to that of tylosin; however, initial dissipation rates were markedly lower (Fig. 1). At day 7, $62-72 \%$ of chlortetracycline remained in the three soils, while around $50 \%$ of tylosin was dissipated by day 7 (Fig. 1). Continuous dissipation of chlortetracycline in soils has also been observed in laboratory and field experiments (Halling-Sorensen et al., 2005; Carlson and Mabury, 2006; Zhang and Zhang, 2010; Fang et al.,

Table 1

Initial $\left(\mathrm{C}_{\mathrm{o}}\right)$ and final (120-day) concentrations of antibiotics $\left(\mu \mathrm{g} \mathrm{kg} \mathrm{k}^{-1}\right)$ in three different soils amended with raw manure, static compost, or turned compost.

\begin{tabular}{|c|c|c|c|c|c|c|c|c|c|c|}
\hline \multirow[t]{2}{*}{ Amendment types } & \multirow[t]{2}{*}{ Soil types } & \multicolumn{2}{|c|}{ Sulfamethazine } & \multicolumn{2}{|l|}{ Tylosin } & \multicolumn{2}{|c|}{ Chlortetracycline } & \multicolumn{3}{|l|}{ Pirlimycin } \\
\hline & & Initial & Final & Initial & Final & Initial & Final & Initial & Day $3^{a}$ & Final \\
\hline Raw manure & $\begin{array}{l}\text { sandy loam } \\
\text { silt loam } \\
\text { silty clay loam }\end{array}$ & $\begin{array}{l}47 \pm 9.9 \\
29 \pm 4.8 \\
32 \pm 7.3\end{array}$ & $\begin{array}{l}18 \pm 3.5 \\
12 \pm 2.3 \\
13 \pm 3.6\end{array}$ & $\begin{array}{l}8.4 \pm 2.6 \\
8.6 \pm 1.1 \\
10 \pm 2.3\end{array}$ & $\begin{array}{l}0.70 \pm 0.07 \\
0.51 \pm 0.03 \\
0.87 \pm 0.07\end{array}$ & $\begin{array}{l}57 \pm 14 \\
80 \pm 13 \\
46 \pm 11\end{array}$ & $\begin{array}{l}17 \pm 2.2 \\
19 \pm 2.4 \\
9.3 \pm 1.0\end{array}$ & $\begin{array}{l}4.6 \pm 0.64 \\
10 \pm 1.8 \\
13 \pm 1.6\end{array}$ & $\begin{array}{l}12 \pm 1.4 \\
19 \pm 1.9 \\
26 \pm 1.7\end{array}$ & $\begin{array}{l}0.79 \pm 0.08 \\
0.47 \pm 0.21 \\
0.63 \pm 0.05\end{array}$ \\
\hline Static compost & $\begin{array}{l}\text { sandy loam } \\
\text { silt loam } \\
\text { silty clay loam }\end{array}$ & $\begin{array}{l}1.6 \pm 0.35 \\
1.1 \pm 0.22 \\
1.5 \pm 0.58\end{array}$ & $\begin{array}{l}1.5 \pm 0.03 \\
1.2 \pm 0.05 \\
1.4 \pm 0.06\end{array}$ & $\begin{array}{l}1.8 \pm 0.35 \\
1.8 \pm 0.40 \\
1.3 \pm 0.20\end{array}$ & $\begin{array}{l}\text { BDL } \\
\text { BDL } \\
\text { BDL }\end{array}$ & $\begin{array}{l}11 \pm 0.38 \\
7.5 \pm 0.52 \\
8.9 \pm 0.50\end{array}$ & $\begin{array}{l}3.1 \pm 0.14 \\
1.8 \pm 0.11 \\
1.8 \pm 0.16\end{array}$ & $\begin{array}{l}\text { BDL } \\
\text { BDL } \\
\text { BDL }\end{array}$ & $\begin{array}{l}\text { BDL } \\
\text { BDL } \\
\text { BDL }\end{array}$ & $\begin{array}{l}\text { BDL } \\
\text { BDL } \\
\text { BDL }\end{array}$ \\
\hline Turned compost & $\begin{array}{l}\text { sandy loam } \\
\text { silt loam } \\
\text { silty clay loam }\end{array}$ & $\begin{array}{l}0.80 \pm 0.12 \\
0.35 \pm 0.03 \\
0.35 \pm 0.08\end{array}$ & $\begin{array}{l}0.78 \pm 0.38 \\
0.43 \pm 0.03 \\
0.39 \pm 0.08\end{array}$ & $\begin{array}{l}0.27 \pm 0.14 \\
0.63 \pm 0.30 \\
1.2 \pm 0.45\end{array}$ & $\begin{array}{l}\text { BDL } \\
\text { BDL } \\
\text { BDL }\end{array}$ & $\begin{array}{l}4.7 \pm 1.2 \\
6.4 \pm 1.9 \\
5.9 \pm 0.57\end{array}$ & $\begin{array}{l}1.1 \pm 0.52 \\
2.4 \pm 1.5 \\
2.1 \pm 0.50\end{array}$ & $\begin{array}{l}\text { BDL } \\
\text { BDL } \\
\text { BDL }\end{array}$ & $\begin{array}{l}\text { BDL } \\
\text { BDL } \\
\text { BDL }\end{array}$ & $\begin{array}{l}\text { BDL } \\
\text { BDL } \\
\text { BDL }\end{array}$ \\
\hline
\end{tabular}

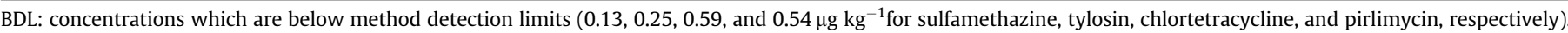

a The initial concentrations of pirlimycin in the raw manure amended soils are the peak concentrations determined at day 3 of the microcosm incubation. 


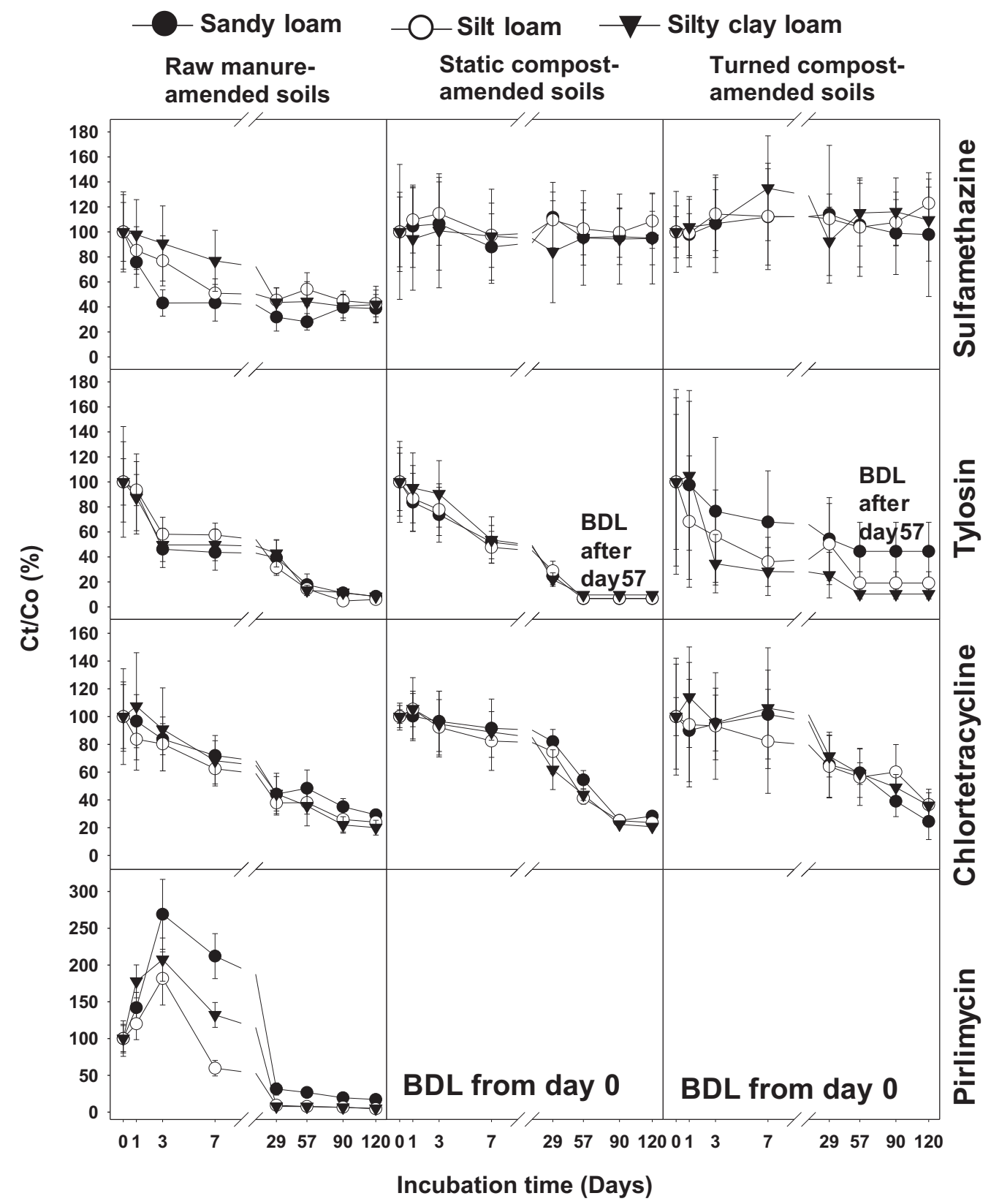

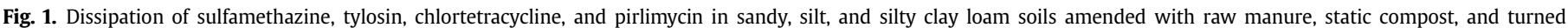
compost. Error bars represent standard deviations from replicate microcosms $(n=3$ ]

2014). In a field study using manure-borne antibiotics, 50\% reduction of chlortetracycline was observed in both a sandy loam and sandy soil within 20-34 and 28-42 d, respectively (HallingSorensen et al., 2005).

In contrast to the above antibiotic dissipation patterns, the levels of pirlimycin in all raw manure-amended soils first increased 1.98 to 2.70 times from day 0 to day 3 , rapidly decreased from day 3 to day 29 , and then remained relatively constant thereafter until day 120 (Fig. 1). The initial spike in pirlimycin concentration was most notable in the sandy loam soil (Table 1). Previous research has shown that pirlimycin administrated to dairy cows can be conjugated in the liver and gastrointestinal tract to form pirlimycinsulfoxide, pirlimycin-sulfone, pirlimycin-adenylate, pirlimycin-uridylate, and pirlimycin sulfoxide-adenylate (Hornish et al., 1998). These conjugates are subsequently excreted into the feces and urine at substantial levels, up to $50 \%$ of the total secreted pirlimycin. Therefore, we hypothesize that the initial observed rise in concentration was likely due to deconjugation of pirlimycin conjugates back to pirlimycin.

\subsubsection{Compost-amended soils}

Although a significant proportion (62-99\%) of manure-borne antibiotics can be transformed during composting (Ray et al., 2017), to the best of our knowledge, no prior study has examined whether the residual antibiotics in finished compost (e.g., Table S2) are subject to further dissipation after application to soil.

The initial concentrations of sulfamethazine in the three soils ranged from 1.1 to $1.6 \mu \mathrm{g} \mathrm{kg}^{-1}$ and from 0.35 to $0.80 \mu \mathrm{g} \mathrm{kg}^{-1}$, after amending with static and turned composts, respectively (Table 1). One prior study indicated that the highest concentration of 
chlortetracycline in soils nearby a swine manure composting facility was $0.85 \mu \mathrm{g} \mathrm{kg}^{-1}$ (Awad et al., 2014). This highlights the importance of understanding the fate of low concentrations of antibiotics in compost-amended soils. In contrast to raw manureamended soils, no dissipation of sulfamethazine was observed in the compost-amended soils over the 120 -day period (Fig. 1), indicating that it may not have been bioavailable to soil microorganisms. This was consistent with the observation that no dissipation of sulfamethazine occurred after day 7 in raw manure-amended soil (Fig. 1). Strong adsorption to compost could be a key factor limiting the bioavailability of sulfamethazine and contributing to its observed persistence.

The initial concentrations of tylosin in soils after application with static compost and turned compost ranged from 1.3 to $1.8 \mu \mathrm{g} \mathrm{kg}^{-1}$ and from 0.27 to $1.2 \mu \mathrm{g} \mathrm{kg}^{-1}$, respectively (Table 1 ). Rapid dissipation was observed within the first $7 \mathrm{~d}$ of microcosm incubation, resulting in $48-54 \%$ and $28-68 \%$ of the initially added tylosin remaining in all three soils for static compost-amended soil and turned compost-amended soil, respectively (Fig. 1). By day 57, tylosin was below detection in all soils applied with compost.

Initial concentrations of chlortetracycline ranged from 7.5 to $11 \mu \mathrm{g} \mathrm{kg}^{-1}$ and from 4.7 to $6.4 \mu \mathrm{g} \mathrm{kg}^{-1}$ (Table 1) after application of static compost and turned compost to the soils, respectively. Compared to tylosin, chlortetracycline dissipation was much slower during the first week. By day 7, 82-92\% and $82-106 \%$ of the initially added chlortetracycline remained in all three soils for static compost-amended soils and turned compost-amended soils, respectively (Fig. 1). After $120 \mathrm{~d}$, chlortetracycline was still above the detection limit, with concentrations ranging from 1.8 to $3.1 \mu \mathrm{g} \mathrm{kg}^{-1}$ and from 1.1 to $2.4 \mu \mathrm{g} \mathrm{kg}^{-1}$ in static and turned compost-amended soils, respectively (Table 1 ).

\subsection{Antibiotic dissipation rates in the soil microcosms}

\subsubsection{Raw manure-amended soils}

Single-phase first order kinetics did not adequately describe the dissipation of the target antibiotics in raw manure-amended soils in this study, as the coefficients of determination $\left(\mathrm{R}^{2}\right)$ varied largely from 0.27 to 0.93 upon fitting the data to a single-phase first order kinetic model. When fitting their dissipation using bi-phasic first order kinetics using the Hockey-Stick model (Sarmah and Rohan, 2011), $\mathrm{R}^{2}$ values ranged from 0.94 to 0.99 . This model consists of two sequential first-order kinetics with the integrated equation shown below:

$C_{t}=C_{o} e^{-k_{1} t_{b}}$, for $\mathrm{t} \leq \mathrm{tb}$, and $C_{t}=C_{0} e^{-k_{1} t_{b}} e^{-k_{2}\left(t-t_{b}\right)}$, for $\mathrm{t}>\mathrm{tb}$

Where $C_{t}$ is the compound concentration $\left(\mu \mathrm{g} \mathrm{kg}^{-1}\right)$ at time $t(\mathrm{~d})$ after application, $C_{0}$ is the initial concentration $\left(\mu \mathrm{g} \mathrm{kg}^{-1}\right), k_{1}$ is the rate constant $\left(\mathrm{d}^{-1}\right)$ until $t=t_{b}$. The time at which rate constant changes from $k_{1}$ to $k_{2}$ is denoted by $t_{b}$ (breakpoint). The breakpoints for sulfamethazine, tylosin, and chlortetracycline were 7,3 , and $29 \mathrm{~d}$, respectively. For pirlimycin, due to the initial deconjugation of its conjugates, its $C_{0}$ is defined as the peak concentration detected at day 3, with a corresponding breakpoint of $29 \mathrm{~d}$ ( $26 \mathrm{~d}$ after day 3 ).

The antibiotic dissipation rate constants in the raw manureamended soils are shown in Table 2. Because the dairy manure matrix is distinct from that of beef cattle manure, the dissipation of pirlimycin is discussed separately. For the three soils, the first phase dissipation rate constants $\left(k_{1}\right)$ ranked in the order of tylo$\sin >$ sulfamethazine $>$ chlortetracycline (Table 2). It has been shown that antibiotic degradation is typically catalyzed by different extracellular hydrolytic enzymes (protease, lipase, and cellulose) released by microorganisms, mainly in the aqueous phase of soil systems (Thiele-Bruhn, 2003). Therefore, the overall dissipation rate of antibiotics is largely affected by their hydrophilicity (Otker and Akmehmet-Balcioglu, 2005; Wegst-Uhrich et al., 2014). Accordingly, the observed order of dissipation rate constants was consistent with the order of the water solubility of these three compounds: tylosin (5000 $\left.\mathrm{mg} \mathrm{L}^{-1}\right)>$ sulfamethazine (1500 $\left.\mathrm{mg} \mathrm{L}^{-1}\right)>$ chlortetracycline ( $600 \mathrm{mg} \mathrm{L}^{-1}$ ) (Table $\left.\mathrm{S} 1\right)$.

The dissipation rate constants of these three antibiotics in the second phase $\left(k_{2}\right)$ were much lower than those in the first phase $\left(k_{1}\right)$ (Table 2). Availability-adjusted first order kinetic models assume that antibiotic availability in soils decreases exponentially with time, largely due to sorption, and have been applied in prior studies with decreasing dissipation rates (Wang et al., 2006; Stoob et al., 2007; Pan and Chu, 2016). Sorption of antibiotics is an important factor affecting the dissipation rate (Otker and Akmehmet-Balcioglu, 2005; Wegst-Uhrich et al., 2014) and thus the partitioning coefficient $\left(k_{d}\right)$ is a key parameter used in estimating the migration potential of aqueous-phase contaminants in contact with solid soil components. Median $k_{d}$ values of sulfamethazine and tylosin reported in prior literature were 3 and $100 \mathrm{~L} \mathrm{~kg}^{-1}$, respectively (Wegst-Uhrich et al., 2014), while the $k_{d}$ values of chlortetracycline ranged from 1208 to $2386 \mathrm{~L} \mathrm{~kg}^{-1}$ (Sarmah et al., 2006). This suggests that soil sorption tendency (loss of availability) follows the order of chlortetracycline $>$ tylosin $>$ sulfamethazine. In the current study, the rate constants for the second phase $\left(k_{2}\right)$ were in the order of tylosin $>$ chlortetracycline $>$ sulfamethazine, which is not consistent with the assumption of loss of bioavailability of the antibiotics in soils due to adsorption. Antibiotics examined in previous studies were spiked into the systems (Wang et al., 2006; Stoob et al., 2007; Pan and Chu, 2016), while manure from antibiotic-treated animals were used in the current study. Partitioning coefficients of antibiotics in manure are likely different from those described for soils (Loke et al., 2002). Also, in prior studies where antibiotics were spiked into manure or soil, it is likely that the interactions of antibiotics with manure or soil components did not achieve a steady state before dissipation. This might have reduced the bioavailability of antibiotics in soil over time. On the other hand, antibiotics in the current study are more likely to have reached equilibrium with the manure matrix after passing through the cattle gut. After application of manure to the soils, it is likely that desorption begins to dominate sorption in the second dissipation phase, at which point aqueous antibiotic dissipation is near completion. The desorption of chlortetracycline could be retarded due to the lowest dissipation rate of the released chlortetracycline (smallest $k_{1}$ ). By contrast, the desorption of tylosin could be accelerated due to the fastest dissipation rate of the released tylosin (highest $k_{1}$ ). Lack of dissipation of sulfamethazine in the second phase may due to a fraction of sulfamethazine that is irreversibly sorbed to the manure.

Pirlimycin dissipation rate constants in all raw manureamended soils were higher during the first phase (day 3-29) compared to the second phase (day 29-120) (Table 2). Similarly, dissipation of clindamycin (a lincosamide antibiotic) in biosolids followed a biphasic pattern, with faster dissipation during the first phase followed by relatively stabilized second phase (Wu et al., 2009).

\subsubsection{Compost-amended soils}

Since sulfamethazine concentrations remained stable in compost-amended soils over the $120 \mathrm{~d}$, no rate constants could be estimated. By contrast, tylosin was below detection limit by day 57 . Therefore, for compost-amended soil, a concentration at half of the detection limit $\left(0.12 \mu \mathrm{g} \mathrm{kg}^{-1}\right)$ of tylosin was assumed beyond day 57, with simple first order kinetics used to fit the curve from day 0 to day 57 , with $R^{2}$ ranged from 0.67 to 0.99 . For chlortetracycline, 
Table 2

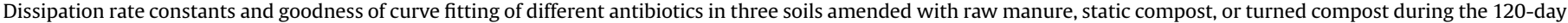
microcosm incubation stud.

\begin{tabular}{|c|c|c|c|c|c|c|c|c|c|}
\hline \multirow{2}{*}{\multicolumn{2}{|c|}{ Raw manure amended soil ${ }^{\mathrm{a}}$}} & \multicolumn{2}{|l|}{ Sulfamethazine } & \multicolumn{2}{|l|}{ Tylosin } & \multicolumn{2}{|c|}{ Chlortetracycline } & \multicolumn{2}{|l|}{ Pirlimycin } \\
\hline & & $k_{1}, k_{2}$ & $R^{2}$ & $k_{1}, k_{2}$ & $R^{2}$ & $k_{1}, k_{2}$ & $R^{2}$ & $k_{1}, k_{2}$ & $R^{2}$ \\
\hline \multicolumn{2}{|c|}{ sandy loam } & $\begin{array}{l}0.116 \pm 0.029 \\
\text { ND }\end{array}$ & 0.94 & $\begin{array}{l}0.261 \pm 0.054 \\
0.016 \pm 0.001\end{array}$ & 0.96 & $\begin{array}{l}0.028 \pm 0.005 \\
0.005 \pm 0.002\end{array}$ & 0.95 & $\begin{array}{l}0.085 \pm 0.004 \\
0.007 \pm 0.001\end{array}$ & 0.99 \\
\hline \multicolumn{2}{|c|}{ silt loam } & $\begin{array}{l}0.092 \pm 0.017 \\
\text { ND }\end{array}$ & 0.96 & $\begin{array}{l}0.192 \pm 0.038 \\
0.023 \pm 0.001\end{array}$ & 0.98 & $\begin{array}{l}0.030 \pm 0.004 \\
0.006 \pm 0.002\end{array}$ & 0.94 & $\begin{array}{l}0.104 \pm 0.010 \\
0.008 \pm 0.001\end{array}$ & 0.90 \\
\hline \multicolumn{2}{|c|}{ silty clay loam } & $\begin{array}{l}0.039 \pm 0.021 \\
\text { ND }\end{array}$ & 0.94 & $\begin{array}{l}0.238 \pm 0.052 \\
0.016 \pm 0.001\end{array}$ & 0.96 & $\begin{array}{l}0.028 \pm 0.005 \\
0.009 \pm 0.002\end{array}$ & 0.95 & $\begin{array}{l}0.127 \pm 0.001 \\
0.005 \pm 0.001\end{array}$ & 0.99 \\
\hline \multicolumn{2}{|c|}{ Compost amended soil $^{\mathrm{b}}$} & $k$ & $R^{2}$ & $k$ & $R^{2}$ & $k$ & $R^{2}$ & $k_{2}$ & $R^{2}$ \\
\hline \multirow[t]{3}{*}{ Static } & Sandy loam & ND & NA & NA & 0.99 & $0.012 \pm 0.001$ & 0.94 & NA & ND \\
\hline & Silt loam & ND & NA & NA & 0.97 & $0.013 \pm 0.001$ & 0.96 & NA & ND \\
\hline & Silty clay loam & ND & NA & NA & 0.97 & $0.014 \pm 0.001$ & 0.98 & NA & ND \\
\hline \multirow[t]{3}{*}{ Turned } & Sandy loam & ND & NA & $0.011 \pm 0.005^{c}$ & 0.85 & $0.01 \pm 0.001$ & 0.96 & NA & ND \\
\hline & Silt loam & ND & NA & $0.019 \pm 0.011^{\mathrm{c}}$ & 0.69 & $0.00 \pm 0.001$ & 0.88 & NA & ND \\
\hline & Silty clay loam & ND & NA & $0.032 \pm 0.008^{c}$ & 0.67 & $0.00 \pm 0.001$ & 0.94 & NA & ND \\
\hline
\end{tabular}

ND: no dissipation ( $\mathrm{k}$ values are close to 0 ).

NA: not available due to below detection limit of pirlimycin in the compost-amended soils.

a Dissipation of antibiotics followed bi-phasic first order kinetics in raw manure-amended soils ( $\mathrm{k} 1$ and $\mathrm{k} 2$ are rate constants for the first and second phases, respectively).

b Dissipation of antibiotics followed single phase first order kinetics in the compost-amended soils.

c The dissipation curves of tylosin in the compost-amended soil are fitted to a single phase first kinetic from day 0 to day 57 , half of the method detection limit $\left(0.12 \mu \mathrm{g}\right.$ kg $\left.{ }^{-1}\right)$ are used to represent the concentrations of tylosin at day 57.

simple first order kinetics were applied to fit the curves for soils mixed with both compost types, with $\mathrm{R}^{2}$ ranging from 0.88 to 0.97 . In compost-amended soils, the rate constants of tylosin in all three soils were greater than those for chlortetracycline, which is consistent with the trend for these two antibiotics in raw manureamended soils. Curve fitting was not conducted for pirlimycin because it was below the detection limit in all compost-amended soils over the duration of the study (Table 2).

\subsection{Antibiotic dissipation half-lives in the soil microcosms}

According to one-way ANOVA, the concentrations of antibiotics in soils were significantly reduced during the incubation period (120 d), except that sulfamethazine in the compost-amended soils. The half-lives of the four antibiotics are summarized in Table 3. In the raw manure amended soils, the half-lives of tylosin, chlortetracycline, and pirlimycin in the second phase were $14,4.6$, and 16 times as long as those in the first phase (Table 3), respectively. This indicates that manure-borne antibiotics could persist in soil at low concentrations for a long period of time. The observed bi-phasic dissipation patterns suggest that a proportion of the manureborne antibiotics is immediately bioavailable and transformed rapidly after manure application. The remaining proportion appears to be released slowly from the manure as dissipation continues.

The BIOWIN model in EPI Suite ${ }^{\mathrm{TM}}$ (USEPA., 2012) was applied to predict half-lives specifically with respect to primary biodegradation, estimating values of $8.67 \mathrm{~d}$ for sulfamerazine and $15 \mathrm{~d}$ for tylosin and chlortetracycline. The EPI Suite ${ }^{\mathrm{TM}}$-predicted half-lives are similar to the dissipation half-lives measured for the rawmanure amended soils, while, for most of the cases, significantly shorter than the second-phase dissipation half-lives and the singlephase half-lives for the compost-amended soils (Table 3). This suggests that the initial antibiotics are more bioavailable in the raw manure-amended soil and their dissipation is most likely biologically-driven. By contrast, in the later phase or in the compost-added soils, these compounds became more recalcitrant and their dissipation is more likely affected by a complex array of biological, chemical, and physical factors.

Varied half-lives of antibiotics have been reported in the literature (Table 3). For example, longer half-lives of sulfamethazine were observed with higher initially spiked concentrations (Lertpaitoonpan, 2008). The author suggested that microbial activity may be inhibited by higher antibiotic concentrations. However, the highest concentration of sulfamethazine determined in the present study, $47 \mu \mathrm{g} \mathrm{kg}^{-1}$ (Table 3), is far below that of this study. An effective concentration (EC 10 values) of $13,000 \mu \mathrm{g} \mathrm{kg}^{-1}$ sulfamethazine was required to influence microbial respiration in rice paddy soils (Liu et al., 2009). Further, even dissipation of antibiotics within the same class can vary. For example, six commonly used antibiotics were spiked into a sandy loam soils with an initial concentration of $2000 \mu \mathrm{g} \mathrm{kg}$ for a 120-day microcosm study to examine their dissipation (Schlusener and Bester, 2006). Among them, the half-lives of four structurally-related macrolides, including tylosin, erythromycin, oleandomycin, and roxithromycin ranged from 8 to $>120 \mathrm{~d}$.

The half-life of pirlimycin in $0.1 \mathrm{~N} \mathrm{NaOH}(\mathrm{pH} 12.5)$ solution and in pure water (under UV exposure) were 5 and $6.7 \mathrm{~d}$ and thus comparable to those estimated for the first phase of dissipation in the raw manure amended soil current study.

In summary, the half-lives of antibiotics in soils reported in the literature appears system-specific and guidance may need to be system specific and incorporate safety factors, assuming the longest observed dissipation rates.

\subsection{Effect of amendment and soil type on dissipation of manure- borne antibiotics in soils}

Potential interactive effects of manure amendment type and soil type on antibiotic dissipation were examined, but none was found (Table 4). Overall, composting appears to be a promising approach for reducing antibiotic input to soils before manure land application. At the same nitrogen application rates, the initial antibiotic concentrations were much lower in compost than in manureamended soils and remained low throughout the study period, with a much lower end-point concentration (Table 1). However, lower initial concentrations can translate to slower subsequent dissipation rates, as was observed for the compost-amended soils relative to the first phase dissipation rates in the raw manureamended soils (Table 2). As suggested by the comparison of the 
Table 3

The half-lives of antibiotics in soils in this study and literatures.

\begin{tabular}{|c|c|c|c|c|}
\hline Antibiotics & $\begin{array}{l}\text { Initial } \\
\left.\text { concentrations ( } \mu \mathrm{g} \mathrm{kg}^{-1}\right)\end{array}$ & Samples & Half-lives (d) & References \\
\hline Sulfamethazine & $\begin{array}{l}29-47^{\mathrm{a}} \\
1.1-1.5^{\mathrm{a}} \\
0.35-0.80^{\mathrm{a}} \\
1000 \text { to } 1,000,000^{\mathrm{b}} \\
500 \text { to } 100,000^{\mathrm{b}} \\
500 \text { to } 100,000^{\mathrm{b}} \\
200^{\mathrm{b}} \\
100^{\mathrm{b}}\end{array}$ & $\begin{array}{l}\text { manure amended-sandy loam/-silt } \\
\text { loam/-silty clay loam } \\
\text { static compost amended-sandy } \\
\text { loam/-silt loam/-silty clay loam } \\
\text { turned compost amended-sandy } \\
\text { loam/-silt loam/-silty clay loam } \\
\text { silt loam/sandy loam } \\
\text { sandy loam } \\
\text { manure amended-sandy loam } \\
\text { manure amended-sandy loam/-clay } \\
\text { loam } \\
\text { clay loam soil }\end{array}$ & $\begin{array}{l}6-18, \text { first phase ND [»120], } \\
\text { second phase } \\
\text { ND [»120] } \\
\text { ND [»120] } \\
18.6 \\
1.3-5.9 \\
1.2-6.6 \\
\text { ND [»28] } \\
24.8\end{array}$ & $\begin{array}{l}\text { (Accinelli et al., 2007) } \\
\text { (Lertpaitoonpan, 2008) } \\
\text { (Bailey et al., 2016) } \\
\text { (Pan and Chu, 2016) }\end{array}$ \\
\hline Tylosin & $\begin{array}{l}8.4-10^{\mathrm{a}} \\
1.3-1.8^{\mathrm{a}} \\
0.27-1.2^{\mathrm{a}} \\
1142^{\mathrm{b}} \\
1408^{\mathrm{b}} \\
2000^{\mathrm{b}} \\
50,000^{\mathrm{b}} \\
50^{\mathrm{a}} \\
25^{\mathrm{a}}\end{array}$ & $\begin{array}{l}\text { manure amended-sandy loam/-silt } \\
\text { loam/-silty clay loam } \\
\text { static compost amended-sandy } \\
\text { loam/-silt loam/-silty clay loam } \\
\text { turned compost amended-sandy } \\
\text { loam/-silt loam/-silty clay loam } \\
\text { sandy loam } \\
\text { manure amended-sandy loam } \\
\text { sandy loam } \\
\text { sandy loam } \\
\text { manure amended-loamy sand } \\
\text { manure amended-sandy }\end{array}$ & $\begin{array}{l}2.7-3.7, \text { first phase } \\
41-44, \text { second phase } \\
15-17 \\
22-63 \\
6.1 \\
4.5 \\
8 \\
7 \\
67 \\
49\end{array}$ & $\begin{array}{l}\text { (Carlson and Mabury, 2006) } \\
\text { (Schlusener and Bester, 2006) } \\
\text { (Hu and Coats, 2007) } \\
\text { (Halling-Sorensen et al., 2005) }\end{array}$ \\
\hline Chlortetracycline & $\begin{array}{l}57-80^{\mathrm{a}} \\
7.5-11^{\mathrm{a}} \\
4.7-6.4^{\mathrm{a}} \\
754^{\mathrm{b}} \\
705^{\mathrm{b}} \\
5000^{\mathrm{b}} \\
5000^{\mathrm{b}} \\
20,000^{\mathrm{b}} \\
20-30^{\mathrm{a}} \\
20-30^{\mathrm{a}}\end{array}$ & $\begin{array}{l}\text { manure amended-sandy loam/-silt } \\
\text { loam/-silty clay loam } \\
\text { static compost amended-sandy } \\
\text { loam/-silt loam/-silty clay loam } \\
\text { turned compost amended-sandy } \\
\text { loam/-silt loam/-silty clay loam } \\
\text { sandy loam } \\
\text { manure amended-sandy loam } \\
\text { loam } \\
\text { manure amended-loam } \\
\text { silt loam } \\
\text { manure amended-loamy sand } \\
\text { manure amended-sandy }\end{array}$ & $\begin{array}{l}23-25 \text {, first phase } 75-144 \text {, } \\
\text { second phase } \\
49-58 \\
61-104 \\
21 \\
24 \\
31.9 \\
37.3 \\
5.5 \\
25 \\
34\end{array}$ & $\begin{array}{l}\text { (Carlson and Mabury, 2006) } \\
\text { (Zhang and Zhang, 2010) } \\
\text { (Fang et al., 2014) } \\
\text { (Halling-Sorensen et al., 2005) }\end{array}$ \\
\hline Pirlimycin & $12-26^{\mathrm{a}}$ & $\begin{array}{l}\text { manure amended-sandy loam/-silt } \\
\text { loam/-silty clay loam }\end{array}$ & $\begin{array}{l}5.5-8.2 \text {, first phase } 87-142 \text {, } \\
\text { second phase }\end{array}$ & This study \\
\hline
\end{tabular}

ND: no dissipation observed within days showed in square brackets.

a Antibioticas in naturally excreted form when manure-based amendments are applied to soil.

b Antibiotics directly spiked into the soil systems.

EPI Suite ${ }^{\mathrm{TM}}$-predicted half-lives and the measured half-lives, antibiotics in compost are less bioavailable compared to raw manure because most of the available fraction is transformed and the residual fraction becomes more recalcitrant during composting. Our prior study observed decreasing dissipation rate of antibiotics during manure composting (Ray et al., 2017). Notably, static versus turned compost did not result in significantly different dissipation patterns or rates in soils (Table 3), which may be related to the high similarity of the small-scale compost conditions (Ray et al., 2017).

Statistically significant differences were not observed for dissipation of manure-borne antibiotics among different types of soil receiving manure application (Table 3 and Table S4). Soil properties, such as $\mathrm{pH}$, organic matter content, and clay content theoretically could affect the partition coefficient of antibiotics (Gao and Pedersen, 2010; Wegst-Uhrich et al., 2014) and, therefore, affect the dissipation of antibiotics in soils. In particular, hydrophobic

Table 4

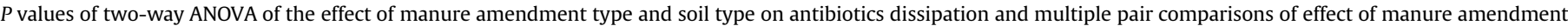
types on antibiotic dissipation.

\begin{tabular}{|c|c|c|c|c|}
\hline Factors & Sulfamethazine & Tylosin & Chlortetracycline & Pirlimycin \\
\hline Amendment type & $<0.0001$ & 0.53 & 0.01 & $N A$ \\
\hline Soil Type & 0.05 & 0.36 & 0.72 & 0.18 \\
\hline Amendment Type $\times$ Soils & 0.12 & 0.11 & 0.81 & $N A$ \\
\hline Pair comparisons of amendment type & Sulfamethazine & Tylosin & Chlortetracycline & Pirlimycin \\
\hline Raw manure vs. Static compost & $<0.0001$ & 0.95 & 0.17 & $N A$ \\
\hline Raw manure vs. Turned compost & $<0.0001$ & 0.51 & 0.01 & $N A$ \\
\hline Static compost vs. Turned compost & 0.06 & 0.71 & 0.44 & $N A$ \\
\hline
\end{tabular}

NA: not available due to below detection limit of pirlimycin in the compost-amended soils. 
interactions between chemicals and the organic matter is considered to be a predominant mechanism of sorption (Zhang et al., 2010). However, these interactions and factors might not be applicable for manure-borne antibiotics because, in contrast to antibiotics that are spiked into soil systems, the manure-borne antibiotics that enter the soils are likely in various complexed forms with the manure matrix, especially organic matter. As a result, soil physico-chemical properties might become less important, as observed by others (Sassman et al., 2007; Bailey et al., 2016).

\subsection{Environmental implications}

Moreso than toxicity, a main concern regarding land application of antibiotic-containing manure is the potential to select for antibiotic resistance and stimulate gene transfer, resulting in accumulation in soils (Knapp et al., 2010, 2011). Selection pressure has been reported to occur at very low antibiotic concentrations, as suggested by susceptible/resistant bacteria competition tests (Gullberg et al., 2011; Sandegren, 2014). Minimal selective antibiotic concentrations (MSCs), which could be several hundred-fold below the minimal inhibitory concentrations (MICs) of susceptible bacteria, have been reported to be capable of enriching for resistant bacteria (Gullberg et al., 2011). Here, the antibiotic resistance selection potential was assessed for the initial and final 120-day concentrations of antibiotic residues in the microcosms. Using the method described by Bengtsson-Palme and Larsson (2016), which assumes that the concentrations of antibiotics that inhibit growth of some bacteria will by consequence have selective effects on the community level, the estimated MSCs of targeted antibiotics were applied to standard risk quotients (Bengtsson-Palme and Larsson, 2016). MSCs were applied as an alternative to toxicity thresholds typically used in the standard RQ model.

The initial sulfamethazine levels were at the upper end of "medium" in raw manure-amended soils (Fig. 2). After $120 \mathrm{~d}$, although sulfamethazine RQ values in the raw-manure amended soils decreased, the concentration levels were still in the "medium" category for antibiotic resistant selection. In composted-amended soils, sulfamethazine RQ values remained $<1$ throughout the 120 day incubation period (Fig. 2). The initial tylosin levels were at the lower end of "high" in raw manure-amended soils and at or close to "medium" in compost amended-soils, with RQ values ranging from 0.1 to 1 or close to 0.1 , respectively (Fig. 2). In contrast to sulfamethazine, the potential for tylosin to select for antibiotic resistance decreased from initial "high" or "medium" levels to "low" for all soils after 120-day incubation. The potential for chlortetracycline to select for antibiotic resistance remained "high" for all the soils during the 120-day incubation. Pirlimycin was detectable only in manure-amended soils. Similar to tylosin, the potential of pirlimycin for antibiotic resistance selection decreased from the lower end of "high" or upper end of "medium" levels to "low" after $120 \mathrm{~d}$ (Fig. 2).

The results of this study suggest that composting manure

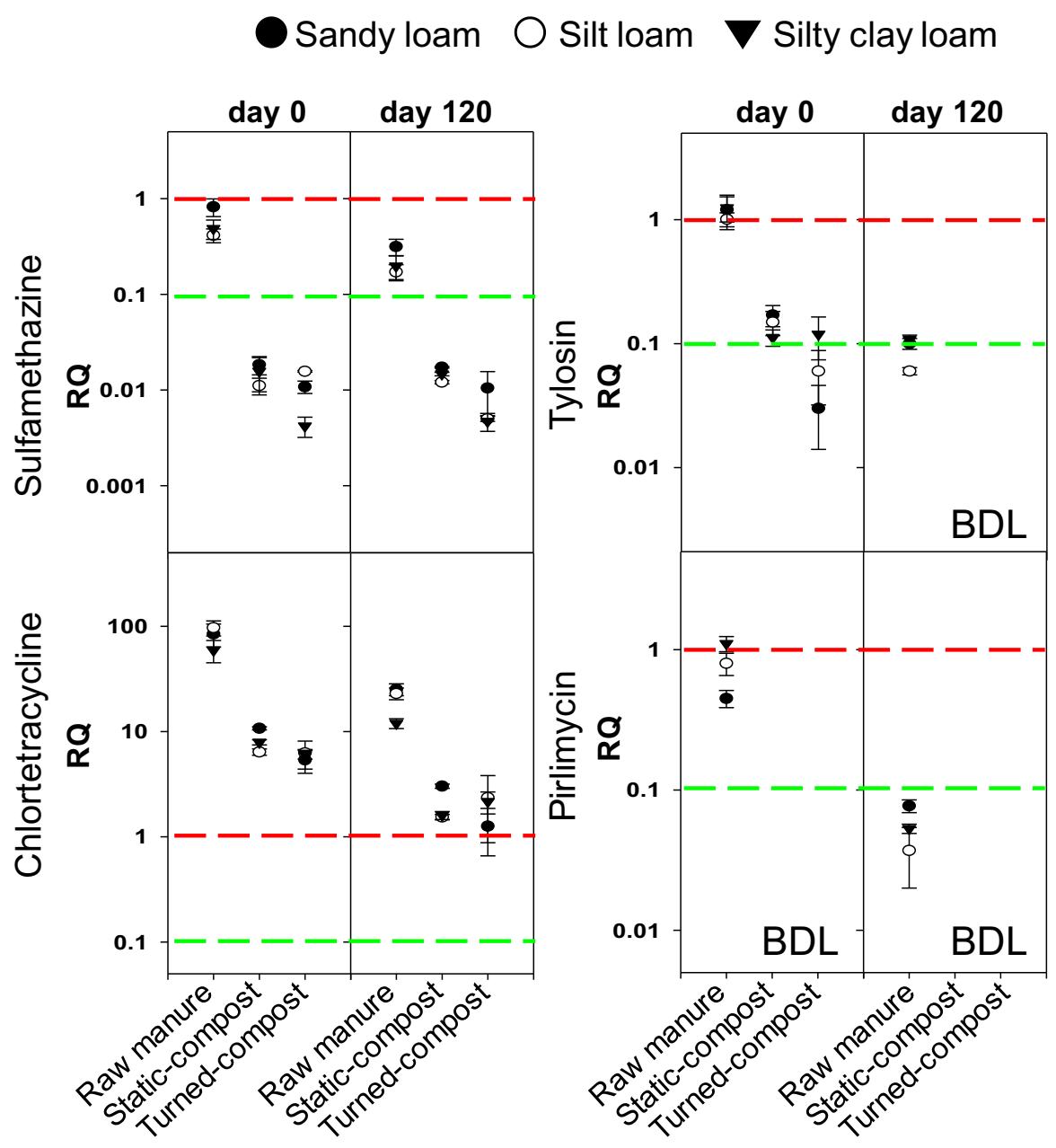

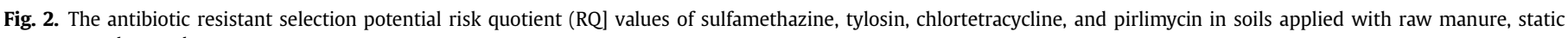
compost, and turned compost. 
reduces the potential for antibiotic resistance selection relative to raw manure application to soils. Further, the results support the conceptual benefits of a waiting period prior to harvest, especially for raw manure-amended soil. However, $120 \mathrm{~d}$ may not be sufficient for some antibiotics to reduce their potential to a "low" risk level for antibiotic resistance selection potential. After incubation for $120 \mathrm{~d}$, the concentrations of antibiotics in raw manure-amended soils were still significantly higher than those in the compostamended soils $(\mathrm{p}<.001)$ (Table S5 and Table S6). The persistence of antibiotics in manure-amended soils and their potential for resistance selection imply that identification of appropriate manure management practice prior to land application warrants attention.

\section{Conclusions}

The study employed a controlled, replicated microcosm approach to understand the effect of composting and soil type on the dissipation of manure-borne antibiotics in soils amended with raw manure or compost. Manure-borne antibiotics, including sulfamethazine and chlortetracycline, can persist in soils at low concentrations for extended periods ( $120 \mathrm{~d}$ ). Extended persistence of these antibiotics in soils indicates the possibility of antibiotic accumulation in soils with repeated input of antibiotics with manure application over time. Dissipation of antibiotics in raw manure-amended soils was significantly faster than in compostamended soils, but composting reduced initial inputs of antibiotics and generally resulted in lower levels of antibiotics by $120 \mathrm{~d}$. Soil type did not have a measurable influence on the fate of manure-borne antibiotics, likely because the complex interactions between antibiotics and manure components in the animals' digestive system and during composting reduce the relevance of soil properties in affecting antibiotic fate. Thus, manure management practices for reducing antibiotic inputs may be widely applicable to various soil types. Further, composting may be advantageous for reducing antibiotic inputs to soil systems, while enforcing a wait period prior to crop harvest may provide additional benefits for reducing the chances of contributing to selection and spread of resistant bacteria.

\section{Acknowledgements}

This study was supported by the USDA NIFA Competitive Grants no. 2014-05280, no 2013-67019-21355, and no. 2013-67021-21140.

\section{Appendix A. Supplementary data}

Supplementary data related to this article can be found at https://doi.org/10.1016/j.chemosphere.2017.12.161.

\section{References}

Accinelli, C., Koskinen, W.C., Becker, J.M., Sadowsky, M.J., 2007. Environmental fate of two sulfonamide antimicrobial agents in soil. J. Agric. Food Chem. 55, 2677-2682.

Awad, Y.M., Kim, S.-C., Abd El-Azeem, S.A.M., Kim, K.-H., Kim, K.-R., Kim, K., Jeon, C., Lee, S.S., Ok, Y.S., 2014. Veterinary antibiotics contamination in water, sediment, and soil near a swine manure composting facility. Environ Earth Sci 71, 1433-1440.

Bailey, C., Spielmeyer, A., Hamscher, G., Schüttrumpf, H., Frings, R.M., 2016. The veterinary antibiotic journey: comparing the behaviour of sulfadiazine, sulfamethazine, sulfamethoxazole and tetracycline in cow excrement and two soils. J. Soils Sediments 16, 1690-1704.

Benetti, C., Dainese, N., Biancotto, G., Piro, R., Mutinelli, F., 2004. Unauthorised antibiotic treatments in beekeeping: development and validation of a method to quantify and confirm tylosin residues in honey using liquid chromatography-tandem mass spectrometric detection. Anal. Chim. Acta 520, 87-92.

Bengtsson-Palme, J., Larsson, D.G., 2016. Concentrations of antibiotics predicted to select for resistant bacteria: proposed limits for environmental regulation. Environ. Int. 86, 140-149.
Carlson, J.C., Mabury, S.A., 2006. Dissipation kinetics and mobility of chlortetracycline, tylosin, and monensin in an agricultural soil in Northumberland County, Ontario, Canada. Environ. Toxicol. Chem. 25, 1-10.

Cengiz, M., Balcioglu, I.A., Oruc, H.H., Cengiz, T.G., 2010. Evaluation of the interaction between soil and antibiotics. J Environ Sci Health B 45, 183-189.

Cessna, A.J., Larney, F.J., Kuchta, S.L., Hao, X., Entz, T., Topp, E., McAllister, T.A., 2011 Veterinary antimicrobials in feedlot manure: dissipation during composting and effects on composting processes. J. Environ. Qual. 40, 188-198.

Chee-Sanford, J.C., Mackie, R.I., Koike, S., Krapac, I.G., Lin, Y.F., Yannarell, A.C. Maxwell, S., Aminov, R.I., 2009. Fate and transport of antibiotic residues and antibiotic resistance genes following land application of manure waste. J. Environ. Qual. 38, 1086-1108.

Chiesa, L., Nobile, M., Arioli, F., Britti, D., Trutic, N., Pavlovic, R., Panseri, S., 2015 Determination of veterinary antibiotics in bovine urine by liquid chromatography-tandem mass spectrometry. Food Chem. 185, 7-15.

Cleary, D.W., Bishop, A.H., Zhang, L., Topp, E., Wellington, E.M., Gaze, W.H., 2016 Long-term antibiotic exposure in soil is associated with changes in microbial community structure and prevalence of class 1 integrons. FEMS Microbiol. Ecol. 92.

Collignon, P.C., Conly, J.M., Andremont, A., McEwen, S.A., Aidara-Kane, A., World Health organization Advisory Group, B.M.o.I.S.o.A.R., 2016. World Health Organization Ranking of Antimicrobials According to Their Importance in Human Medicine: A Critical Step for Developing Risk Management Strategies to Control Antimicrobial Resistance From Food Animal Production. Clin Infect Dis 63, 1087-1093.

Dolliver, H., Gupta, S., Noll, S., 2008. Antibiotic degradation during manure composting. J. Environ. Qual. 37, 1245-1253.

Done, H.Y., Venkatesan, A.K., Halden, R.U., 2015. Does the recent growth of aquaculture create antibiotic resistance threats different from those associated with land animal production in agriculture? AAPS J. 17, 513-524.

Evanylo, G.K., 2009. Agricultura Land Application of Biosolids in Virginia: Managing Biosolids for Agricultural Use. Virginia Cooperative Extension.

Fang, H., Han, Y., Yin, Y., Pan, X., Yu, Y., 2014. Variations in dissipation rate, microbial function and antibiotic resistance due to repeated introductions of manure containing sulfadiazine and chlortetracycline to soil. Chemosphere 96, 51-56.

FDA, 2014. Food Safety Modernization Act Facts: Biological Soil Amendments: Subpart F, 2014. Accessed online at: http://www.fda.gov/downloads/Food/ GuidanceRegulation/FSMA/UCM359281.pdf.

Gao, J., Pedersen, J.A., 2010. Sorption of sulfonamide antimicrobial agents to humic acid-clay complexes. J. Environ. Qual. 39, 228-235.

Gullberg, E., Cao, S., Berg, O.G., Ilback, C., Sandegren, L., Hughes, D., Andersson, D.I., 2011. Selection of resistant bacteria at very low antibiotic concentrations. PLoS Pathog. 7, e1002158.

Halling-Sorensen, B., Jacobsen, A.M., Jensen, J., Sengelov, G., Vaclavik, E., Ingerslev, F. 2005. Dissipation and effects of chlortetracycline and tylosin in two agricultural soils: a field-scale study in southern Denmark. Environ. Toxicol. Chem. 24, 802-810.

Heuer, H., Focks, A., Lamshöft, M., Smalla, K., Matthies, M., Spiteller, M., 2008. Fate of sulfadiazine administered to pigs and its quantitative effect on the dynamics of bacterial resistance genes in manure and manured soil. Soil Biol. Biochem. 40, 1892-1900.

Ho, Y.B., Zakaria, M.P., Latif, P.A., Saari, N., 2014. Occurrence of veterinary antibiotics and progesterone in broiler manure and agricultural soil in Malaysia. Sci. Total Environ. 488-489, 261-267.

Ho, Y.B., Zakaria, M.P., Latif, P.A., Saari, N., 2015. Environmental risk assessment for veterinary antibiotics and hormone in Malaysian agricultural soil. Iran. J. Public Health 43, 67-71.

Hornish, R.E., Roof, R.D., Wiest, J.R., 1998. Pirlimycin residue in bovine liver-a case of reverse metabolism. Analyst 123, 2463-2467.

Hu, D., Coats, J.R., 2007. Aerobic degradation and photolysis of tylosin in water and soil. Environ. Toxicol. Chem. 26, 884-889.

Jechalke, S., Heuer, H., Siemens, J., Amelung, W., Smalla, K., 2014. Fate and effects of veterinary antibiotics in soil. Trends Microbiol. 22, 536-545.

Jjemba, P.K., 2002. The potential impact of veterinary and human therapeutic agents in manure and biosolids on plants grown on arable land: a review. Agric. Ecosyst. Environ. 93, 267-278.

Knapp, C.W., Dolfing, J., Ehlert, P.A., Graham, D.W., 2010. Evidence of increasing antibiotic resistance gene abundances in archived soils since 1940. Environ. Sci. Technol. 44, 580-587.

Knapp, C.W., McCluskey, S.M., Singh, B.K., Campbell, C.D., Hudson, G., Graham, D.W. 2011. Antibiotic resistance gene abundances correlate with metal and geochemical conditions in archived Scottish soils. PLos One 6, e27300.

Kwon, J.W., Xia, K., 2012. Fate of triclosan and triclocarban in soil columns with and without biosolids surface application. Environ. Toxicol. Chem. 31, 262-269.

Lertpaitoonpan, W., 2008. Sorption, Degradation, and Transport of Sulfamethazine in Soils and Manure-amended Soils. Graduate Theses and Dissertations, Paper 11180.

Lertpaitoonpan, W., Moorman, T.B., Ong, S.K., 2015. Effect of swine manure on sulfamethazine degradation in aerobic and anaerobic soils. Water Air Soil Pollut. $226,81$.

Li, C., Chen, J., Wang, J., Ma, Z., Han, P., Luan, Y., Lu, A., 2015. Occurrence of antibiotics in soils and manures from greenhouse vegetable production bases of Beijing, China and an associated risk assessment. Sci. Total Environ. 521-522, 101-107.

Liu, F., Ying, G.-G., Yang, J.-F., Zhou, L.-J., Tao, R., Wang, L., Zhang, L.-J., Peng, P.-A., 2010. Dissipation of sulfamethoxazole, trimethoprim and tylosin in a soil under 
aerobic and anoxic conditions. Environ. Chem. 7, 370-376.

Liu, F. Ying, G.G., Tao, R. Zhao, J.L., Yang, J.F., Zhao, L.F. 2009. Effects of six selected antibiotics on plant growth and soil microbial and enzymatic activities. Environ. Pollut. 157, 1636-1642.

Loke, M.L., Tjornelund, J., Halling-Sorensen, B., 2002. Determination of the distribution coefficient (log $\mathrm{Kd}$ ) of oxytetracycline, tylosin $\mathrm{A}$, olaquindox and metronidazole in manure. Chemosphere 48, 351-361.

Martinez-Carballo, E., Gonzalez-Barreiro, C., Scharf, S., Gans, O., 2007. Environmental monitoring study of selected veterinary antibiotics in animal manure and soils in Austria. Environ. Pollut. 148, 570-579.

Montforts, M.H., Kalf, D.F., van Vlaardingen, P.L., Linders, J.B., 1999. The exposure assessment for veterinary medicinal products. Sci. Total Environ. 225, 119-133.

Nordenholt, R.M., Goyne, K.W. Kremer, R.J., Lin, C.H., Lerch, R.N., Veum, K.S., 2016. Veterinary antibiotic effects on atrazine degradation and soil microorganisms. J. Environ. Qual. 45, 565-575.

Otker, H.M., Akmehmet-Balcioglu, I., 2005. Adsorption and degradation of enrofloxacin, a veterinary antibiotic on natural zeolite. J. Hazard Mater. 122, $251-258$.

Pan, M., Chu, L.M., 2016. Adsorption and degradation of five selected antibiotics in agricultural soil. Sci. Total Environ. 545-546, 48-56.

Ray, P., Chen, C., Knowlton, K.F., Pruden, A., Xia, K., 2017. Fate and effect of antibiotics in beef and dairy manure during static and turned composting. J. Environ. Qual. $46,45-54$

Ray, P., Knowlton, K.F., Shang, C., Xia, K., 2014. Method development and validation: solid Phase extraction-ultra performance liquid chromatography-tandem mass spectrometry quantification of pirlimycin in bovine feces and urine. J AOAC Int 97, 1730-1736.

Sandegren, L., 2014. Selection of antibiotic resistance at very low antibiotic concentrations. Ups. J. Med. Sci. 119, 103-107.

Sarmah, A.K., Meyer, M.T., Boxall, A.B., 2006. A global perspective on the use, sales, exposure pathways, occurrence, fate and effects of veterinary antibiotics (VAs) in the environment. Chemosphere 65, 725-759.

Sarmah, A.K., Rohan, M., 2011. Evaluation of four mathematical models to describe dissipation kinetics of 4-n-nonylphenol and bisphenol-A in groundwateraquifer material slurry. J. Environ. Monit. 13, 157-166.

Sassman, S.A., Lee, L.S., 2007. Sorption and degradation in soils of veterinary ionophore antibiotics: monensin and lasalocid. Environ. Toxicol. Chem. 26, $1614-1621$.

Sassman, S.A., Sarmah, A.K., Lee, L.S., 2007. Sorption of tylosin A, D, and A-aldol and degradation of tylosin A in soils. Environ. Toxicol. Chem. 26, 1629-1635.

Schlusener, M.P., Bester, K., 2006. Persistence of antibiotics such as macrolides, tiamulin and salinomycin in soil. Environ. Pollut. 143, 565-571.

Smallidge, R.L., Albert, K., 2000. Determination of sulfamethazine in swine and cattle feed by reversed-phase liquid chromatography with post-column derivatization: collaborative study. J AOAC Int 83, 260-268.

Srinivasan, P. Sarmah, A.K., 2014. Dissipation of sulfamethoxazole in pasture soils as affected by soil and environmental factors. Sci. Total Environ. 479-480, 284-291.

Stoob, K., Singer, H.P., Mueller, S.R., Schwarzenbach, R.P., Stamm, C.H., 2007. Dissipation and transport of veterinary sulfonamide antibiotics after manure application to grassland in a small catchment. Environ. Sci. Technol. 41, 7349-7355.

Thiele-Bruhn, S., 2003. Pharmaceutical antibiotic compounds in soils - a review. J. Plant Nutr. Soil Sci. 166, 145-167.

Thomaidi, V.S., Stasinakis, A.S., Borova, V.L., Thomaidis, N.S., 2016. Assessing the risk associated with the presence of emerging organic contaminants in sludgeamended soil: a country-level analysis. Sci. Total Environ. 548-549, 280-288.

Tukey, J.W., 1949. Comparing individual means in the analysis of variance. Biometrics 5, 99-114.

USDA, 2012. Guide for Organic Crop Producers. Accessed online at. https://www. ams.usda.gov/sites/default/files/media/GuideForOrganicCropProducers.pdf.

USEPA, 2008a. Fate, Transport and Transformation Test Guidelines: OPPTS 835.0001 Principles and Strategies Related to Biodegradation Testing of Organic Chemicals under the Toxic Substances Control Act (TSCA).

USEPA, 2008b. Fate, Transport and Transformation Test Guidelines: OPPTS 835.1230 Adsorption/Desorption (Batch Equilibrium).

USEPA, 2012. Estimation Programs Interface Suite ${ }^{\mathrm{TM}}$ for Microsoft ${ }^{\circledR}$ Windows, V. 4.11. United States Environmental Protection Agency, Washington, DC, USA. Accessed online at. https://www.epa.gov/tsca-screening-tools/epi-suitetmestimation-program-interface\#citing.

Wang, Q., Guo, M., Yates, S.R., 2006. Degradation kinetics of manure-derived sulfadimethoxine in amended soil. J. Agric. Food Chem. 54, 157-163.

Wegst-Uhrich, S.R., Navarro, D.A., Zimmerman, L., Aga, D.S., 2014. Assessing antibiotic sorption in soil: a literature review and new case studies on sulfonamides and macrolides. Chem. Cent. J. 8, 5.

Wu, C., Spongberg, A.L., Witter, J.D., 2009. Sorption and biodegradation of selected antibiotics in biosolids. J Environ Sci Health A Tox Hazard Subst Environ Eng 44 454-461.

Yang, Y., Owino, A.A., Gao, Y., Yan, X., Xu, C., Wang, J., 2016. Occurrence, composition and risk assessment of antibiotics in soils from Kenya, Africa. Ecotoxicology 25, 1194-1201.

Zhang, G.X., Liu, X.T., Sun, K., Zhao, Y., Lin, C.Y., 2010. Sorption of tetracycline to sediments and soils: assessing the roles of $\mathrm{pH}$, the presence of cadmium and properties of sediments and soils. Front Environ Sci En 4, 421-429.

Zhang, M., Zhang, H., 2010. Thermal degradation of chloroteracycline in animal manure and soil. In: Xu, J., Huang, P.M. (Eds.), Molecular Environmental Soil Science at the Interfaces in the Earth's Critical Zone. Springer Berlin Heidelberg, Berlin, Heidelberg, pp. 229-231. 